\title{
Pencak Silat Basic Motion Learning Through Tactical Approach for Junior High School Students
}

\author{
Weny Sasmitha *, Suwirman \\ Physical Education Programs \\ Sport Science Faculty \\ Padang State University \\ *wenysasmitha@fik.unp.ac.id
}

\author{
Ikhwanul Arifan, Dessi Purnama S \\ Sports Coaching Education Program \\ Faculty of Sport Science \\ Padang State University
}

\begin{abstract}
This study aimed to develop a model of learning tools to make the learning activities became more optimal than before. This research used the ADDIE model development method, which had five development phases, namely: Analysis, Design, Development, Implementation, and Evaluation. The learning model used in this research was the tactical approach model, and the learning tools being developed were syllabus, lesson plan, Students Worksheet, Hand out, and instructional implementation guide. The research instrument used interviews, observation, validation questionnaire, and practice test to measure the students' learning outcomes necessary motion of Pencak silat. Data analysis used quantitative and qualitative descriptive analysis. This study produced learning tools (syllabus, lesson plan, Students Worksheet, Hand out, and instructional implementation guides) that had been tested for its validity, practicality, and effectiveness to be used in learning necessary motion of Pencak silat.
\end{abstract}

Keywords- Basic motion learning, Pencak silat, tactical approach

\section{INTRODUCTION}

Improving the quality of national education is an obligatory task that must be carried out together. Because, this is directly related to the quality of the next generation. Quality improvement is implemented so that national educational activities are always accomplished in accordance with the purpose and function of the national education itself. Facing the development of science and technology advances rapidly at this time, a teacher must be flexible in order to develop and adapt to the changes. Which is expected to generate a process of learning the latest and in accordance with the characteristics and needs of learners.

Physical education, sport and health is one of the compulsory subjects in each unit level primary and secondary "education in Indonesia curriculum primary and secondary education shall contain: (a) religious education, (b) Civic Education, (c) Language, (d) mathematics, (e) Natural Sciences, (f) Social Sciences, (g) Arts and Culture, (h) Physical Education and Sport, (i) motion / Vocational, and (j) Local Content" [1]. With this explanation, it can be seen clearly that physical education and sport is one of the compulsory subjects included in the national education system in Indonesia. In other words, the quality of the learning activities of physical exercise and health also have an impact on the quality of national education.

Physical education and sport is essentially an integral part of the overall education system, aims to develop aspects of physical fitness, motor skills, critical thinking, emotional stability, and many others involved in three areas of education. "Physical education is a learning process that involves physical activity in learning activities to improve motion, fitness, knowledge and attitudes that contribute to the development and improvement of the optimal" [2]. "Physical education and sport is a process of learning through physical activity designed to improve physical fitness, develop motor movement, knowledge and behavior of healthy and active life, sportsmanship and emotional intelligence" [3]. From this sense may be mentioned that physical education and sport is an educational process that uses physical activity as a medium to develop their potential learners both in terms of psychomotor, cognitive, and affective. Sport is one of the tools used for an advisory physical activity in the learning process of physical exercise and health education.

One scope of learning in physical education, sports and health or shortened by PJOK in junior secondary school is a martial activity. Teachers can choose the activities that will be taught self-defense in accordance with the ability of teachers and learners' needs. SMPN 1 Salimpaung is one school located in the district Salimpaung, Tanah Datar. At the school's neighborhood, there are several traditional martial arts universities are developing. Some learners are also active in school activities, so this became the basis for the teacher to choose a martial arts as martial activity of learning materials in learning activities at SMPN 1 Salimpaung PJOK. Other than that, there are a lot of traditional martial arts stream that comes from this district, and expanded to the international level, including the flow of Kumango silat, silat Lintau flow, flow tuo silat, silat flow tiger, martial flow staralak, and others - others. This makes the local government recommends that customs and cultural preservation activities carried out starting from an early age, one of them by studying at the unit level of education there.

In addition to martial arts it is one of the original culture of Indonesian people who believed that the martial arts have been around since prehistoric times. Because of the time humans have to face the harsh nature, aiming to 
continue their lives in the fight against wild animals, and eventually humans develop the movements of martial arts into martial aspect. "Pencak Silat is the result of human culture Indonesia to defend and maintain the existence of (independence) and integrity (united) to the surrounding natural environment and to achieve harmony of life in order to increase faith and piety to God Almighty" [4]. From this definition it can be said that the study Pencak Silat is one attempt to pass and maintain Indonesian culture to the next generation.

Based on the characteristics of schools and learners, learning activities pencak silat martial activities in SMPN 1 Salimpaung certainly will not face such constraints mean, this is because most of the students there who already have a background in martial arts. However, in practice in the field of teachers difficulties in achieving learning goals, especially for class VII. Limited availability of existing learning tools such as instructional materials still held in accordance with the characteristics of learners in class VII SMPN 1 Salimpaung. Other than that, lack of time and knowledge possessed by the teacher to undertake the development of the learning model used and the development of learning tools that are needed makes the implementation of learning basic movements of martial arts has become less optimal in achieving learning goals. Therefore, this study aims to develop the basic learning martial arts motion for class VII in order to re-optimal learning activities.

\section{METHODOLOGY}

In accordance with the objectives to be achieved is to develop the martial arts learning basic movements appropriate for students of class VII SMPN 1 Salimpaung, "then this type of research is ADDIE model development" [5]. The study was conducted at SMPN 1 Salimpaung in August s / d in December 2017, with the objective characteristics of the study was the students of class VII SMPN 1 Salimpaung.

Step - step development by starting with needs analysis activities carried out by way of a preliminary study through interviews with teachers PJOK SMPN1 Salimpaung to obtain data about the current state of learning and needs analysis. Subsequently Design is an activity undertaken to develop and design a learning device is required in accordance with the results of the needs analysis. Design activities carried out by FGD (focuss Group Discussion) involving 4 Master PJOK SMP. Development is the stage of development activities. The results of the activities of Design, Validation by experts (involving 3 experts) as well as tested (involving 12 learners class VII SMPN 2 Tanjung Baru) and assessed by the practitioner (involving 2 Practitioner).

Implementation is a device developed implementation activities, conducted in November 2017 at SMPN 1 Salimpaung. In this activity the class VII is divided into two classes of learning, learning as a class 1 class 1 class control and experimental classroom learning as it aims to make it easier look at the effectiveness of the learning device used. Evaluation is an assessment of the development activities carried out either pertahap or overall development that lead to the conclusion that the device developed has proven validity, practicalities, and effectiveness for use in basic motion learning activities for students of martial arts class VII.

Analysis of the data is a step performed after collecting the data. The type of data in this study consisted of qualitative data (interviews and direct observation) and quantitative data (though the results of questionnaire data validation, assessment questionnaire practitioners, and if the data of learners). Analisisi research data using qualitative and quantitative descriptive analysis.

\section{RESULT}

Data analysis needs obtained through preliminary research activities, by conducting interviews with teachers PJOK SMPN1 Salimpaung on 21, 22 and August 23, 2017. Then the data analysis and produce a needs analysis for learning basic movements of martial arts as follows: (1 ) It takes a learning model that is able to improve and balance the activity of learners in the learning process the basic motion martial arts, have forms of small game that utilizes the basic movements of martial arts to attract and motivate learners in the learning process. (2) The device / media additional learning and the use of simple equipment or modifications to help and support learners in the learning process of basic motion martial art.

Design learning tools prepared in accordance with the results of FGD on September 22, 2017 involving 4 junior PJOK teacher as a member of the Forum. "The results of the discussion can be described as follows: (1) The learning model used is a model approach or TGfU Tactical models" [6]. (2) The form of play used in the adaptation of several small games are modified to use the basic motion martial art. (3) The learning tools are used (arranged) consists of: Syllabus (refer to Curriculum 2013 and the model tactical approach), RPP or Learning Implementation Plan (refer to Curriculum 2013 and the model tactical approach), Instructional Materials in the form of handouts and worksheets.

The resulting product feasibility test conducted by validity through expert assessment and test the practicalities through assessment practitioners. The validity of the device is done by bringing the learning device has been prepared for and then evaluated using a questionnaire with Likert scale. In the questionnaire, there are 4 categories of assessment in accordance with the assessment indicators. Assessment categories namely: excellent (SB), good (B), is not good (TB), and is not very good (STB). Each category is given a rating score / number and then the number of scores obtained divided by the maximum score and then multiplied by 100 to produce a score that determines the validity of the device. Analysis of the answers given by the experts through a questionnaire concluded that the device used is composed of, materials, syllabus, lesson plans, and the Guidelines for implementation is in the category is valid and can be used, with details as follows: LKS teaching materials in the form of expert values obtained $86.641,77.63$ of experts 2 , and 80.26 of experts 3 , to obtain the average value 81.6 of which are in the Good category / VALID and usable. Hand out teaching materials in the form of expert values obtained $84.621,76.92$ of experts 2, and 80.77 of 3 experts, in order to obtain an average value of 80.8 which is in the category Good / VALID and usable. Syllabus values obtained from expert $83.331,79.17$ of experts 2, and 87.5 from 3 experts, 
in order to obtain an average value of 83.3 which is in the category Good / VALID and usable. RPP values obtained 83.33 of experts $1,87.5$ of experts 2 , and 83.33 of 3 experts, in order to obtain an average value of 84,7 which is in the category Good / VALID and usable. Guidelines for implementation of learning values obtained from expert $77.271,84.09$ of experts 2, and 81.82 of 3 experts, in order to obtain an average value of 81.1 which is in the category Good / Valid. For more details see in Figure 1.

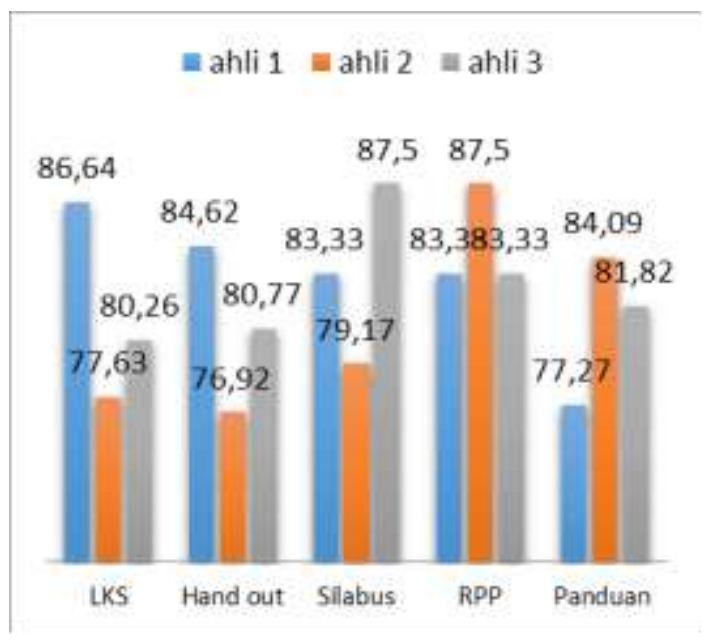

Figure 1. Results of Device Evaluation by Experts

Practicalities device consists of two activities, namely: assessment given by the practitioner through a questionnaire and assessment through interviews given by practitioners as well as students who are involved in culture. Results if the practitioner assessment questionnaire data obtained the following data: LKS teaching materials in the form of values obtained from practitioners 1 at 93.42, and from practitioners 2 obtained value of 82.89 to obtain an average value of 88.16 is the category of Good and practical / usable. Hand out teaching materials in the form of values obtained from practitioners 1 at 88.48 , and from practitioners 2 obtained value of 82.69 , in order to obtain an average value of 85.58 which is the category of Good and practical / usable. Syllabus values obtained from practitioners 187.5 , and from practitioners 2 obtained a value of 87.5 , to obtain an average value of 87.5 in the category Good and practical / usable. RPP values obtained from practitioners 1 amounted to 83.33 , and from practitioners 2 obtained 91.67 value, to obtain an average value of 87.5 in the category Good and practical / usable. Guidelines for implementation of learning values obtained from practitioners 1 at 84.09 and practitioners 2 obtained value of 86.36 to obtain an average value of 85.23 is the category of Good and practical / usable. For more details see in Figure 2. 5 are in the category of Good and practical / usable. Guidelines for implementation of learning values obtained from practitioners 1 at 84.09 and practitioners 2 obtained value of 86.36 to obtain an average value of 85.23 is the category of Good and practical / usable. For more details see in Figure 2. 5 are in the category of Good and practical / usable. Guidelines for implementation of learning values obtained from practitioners 1 at 84.09 and practitioners 2 obtained value of 86.36 to obtain an average value of 85.23 is the category of Good and practical / usable. For more details see in Figure 2.

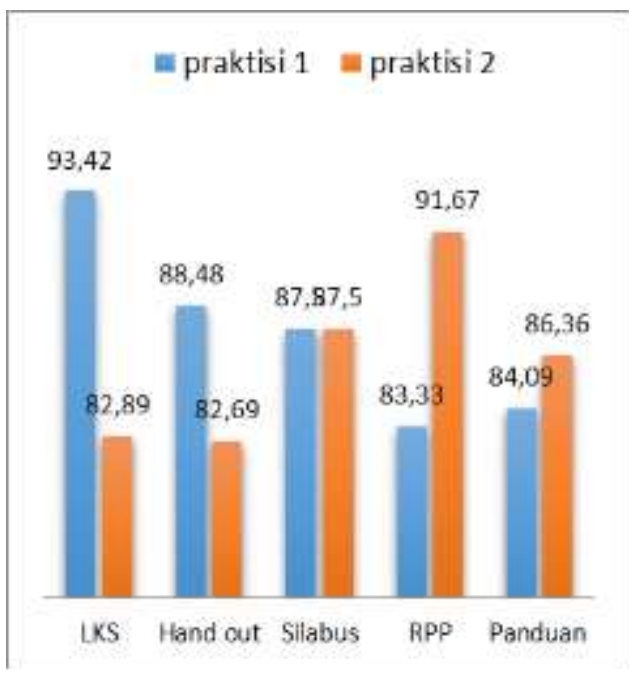

Figure 2. Evaluation Tool by Practitioners

While the results of interviews with learners and practitioners indicate that the device has been tested practical learning / learning activities can be used in martial arts basic motion for class VII.

The device is obtained by comparing the effectiveness of learning outcomes of students, the results of direct observation and interviews with teachers and students in each classroom learning. Analysis of Results of learners performed using the t test. with the proviso that the analysis of test data must be normal and homogeneous. Normality test and homogeneity test was performed using SPSS.16 applications [8], and showed that the data were normally distributed and homogeneous. Having obtained the value $t$ test $\mathrm{t}=2,598$ with sig. 2 tailed 0.006 . It may be mentioned that the study of students in the class that uses the learning device better than the learning outcomes of students in the control class.

\section{DISCUSSION}

Product development efforts undertaken in this study is an effort to resolve the problems and obstacles encountered in conducting basic motion learning martial arts in schools, especially in learning activities PJOK in Junior High School. In this study targets schools are already conducting basic motion learning martial arts in the previous semester despite the lesson activities are still not in accordance with what was designed by the teacher. This is one problem that is not only faced by SMPN 1 Salimpaung only.

Many studies conducted to support the development of learning activities in the school of martial arts. However, the limited facilities and infrastructure owned at school certainly also inhibit the spread of the product that has been developed. So this research is trying to focus on how the products more simple and able to be used in the learning activities for the basic movements of martial arts throughout the school and allows teachers to implement them.

This study overall have strengths and weaknesses, this is due to the limited number of researchers in conducting research. The limited research time coupled with the limited number of schools involved and other limitations. The following will describe the strengths and weaknesses of the products produced in this study. 
"The strength of products produced in this study: (a) model that is used to increase motor activity, the study of students as well as the efficient use of time" [7]. (B) The syllabus and lesson plans have been prepared in accordance with the curriculum in 2013 and adapted to the learning model used. (C) Hand out worksheets and can help implement optimal learning activities. (D) Guidelines for implementation of learning provide an alternative implementation of the basic motion learning martial arts for teachers in using the model of a tactical approach.

The resulting weakness research products: (a) learning model used in the study had a limited subject matter. (b) The syllabus and lesson plans are developed only for one material.(C) Hand out worksheets and designed with the view that they are simple and only includes material pencak silat martial activity for grade VII. (D) Guidelines for implementation of learning are prepared with a simple display and is still in print.

\section{CONCLUSION}

Based on the description of research activities that have been undertaken, the results can be summarized as follows:

1.Kegiatan learning basic movements of martial arts for students of class VII SMPN 1 Salimpaung previously using demonstration and drill method, on motion activity learning activities of students in the learning process is uneven and less effective as well as teaching materials are used only use textbooks that no library at the school so as to further learning activities required a development of the learning model that activity evenly learners and learning software development in accordance with the learning model used.

2.Model learning used in this study is a model of tactical approaches (TGfU model) as well as learning tools developed are: syllabus, lesson plans, worksheets, Hand outs, and guide the implementation of learning that was conceived and developed in accordance with the model tactical approach. Learning devices using ADDIE development model that has 5 development cycle, namely: Analysis of preliminary research form which produces analyzes current learning activities and requirements analysis. Design is a stage of preparing and designing the device is done by the study of literature and discussions with subject teachers PJOK. Development is a development stage after the evaluation and revision by experts and practitioners use a questionnaire.

3. Validasi learning device carried by assessment by experts using a questionnaire, obtained an average value of 81.6 LKS, Hand out with a value of 80.8 , syllabus with a value of
83.3, RPP with a value of 84.7, and guide the implementation of learning with a value of 81.1, it was concluded that the learning device is in either category / Valid. After the appropriate repairs and revision suggestions of experts tested the device on and rated by 2 practitioners use a questionnaire to obtain LKS value of 88.16, Hand out the value of 85.58 , with a value of 87.5 syllabus, lesson plans with a value of 87,5 , and guide the implementation of learning with a value of 85.23 , it was concluded that the device is in either category / Practical for use. Effectiveness of products developed on learning activities basic motion martial arts performed by comparing the motion activity learners, efficient use of instructional time, and the value of the study of students in classes that use the model tactical approach (experimental group) with a class that uses the conventional model (class control). Showed that the motor activity of students in the experimental class is better than the motion activity of students in the control class, efficient use of time in the experimental class is better than the control class, as well as the value of the study of students experimental class have significant differences evidenced by the value of $\mathrm{t}=2.598$ with sig. (2-tailed) $=0.012 / 2=0.006$ $<0.05$ so that it can be concluded that the value of teaching learners in the experimental class is better than the value of teaching learners in the control class. Overall conclusion is the development of learning tools through tactical approach proved Valid, Practical and Effective for learning basic movements of martial arts for students of class VII SMPN 1 Salimpaung.

\section{REFERENCES}

[1] Undang - Undang Republik Indonesia Nomor 20 Tahun 2003 Tentang Sistem Kependidikan Nasional. Jakarta: BP. Cipta Jaya. (2006).

[2] A.C Bucher \& A.D Wuest. "Foundation of Physical Education, Exercise Science, and Sport. New York: McGraw-Hill.Radcliffe, J. C \& Farentinos, RC. Plyometrics Explosive Power Training". 2nd ed. Champaign, IIIionis: Human kinetics Published, Inc. 1985. (2006).

[3] Gusril. "Perkembangan Motorik Pada Masa Anak - Anak". Padang: UNP Press. 2016. pp 25-26.

[4] Mulyana. 'Pendidikan Pencak Silat (Membangun Jati Diri dan Karakter Bangsa”. Bandung: PT. Remaja Rosdakarya. 2014. Pp. 34-35.

[5] Sugiyono. "Metode Penelitian Kuantitatif, Kualitatif, dan R\&D". Bandung: Alfabeta. 2016. pp 45-46.

[6] Griffin, L. Linda. "Teaching Games for Understanding (Theory, Research, and Practice)". Champaign: Human Kinetics. 2005. Pp. 45.

[7] S. Winarni. "TGfU Sebuah Inovasi Pembelajaran Permainan". Jurnal Pendidikan Jasmani Indonesia, vol. 5, No. 2, pp 11-16. November 2008

[8] Kadir. "Statistika Terapan (Konsep, Contoh dan analisis Data dengan Program SPSS/Lisrel dalam Penelitian)". Jakarta: PT. Raja Grafindo Persada. 2015. pp 28. 